\title{
Capacity for Moderate Exercise in Obese Subjects after Adaptation to a Hypocaloric, Ketogenic Diet
}

\author{
Stephen D. Phinney, Edward S. Horton, Ethan A. H. Sims, John S. Hanson, \\ Elliot Danforth, Jr., and Betty M. LaGrange, Department of Medicine, \\ University of Vermont College of Medicine, Burlington, Vermont 05405
}

\begin{abstract}
A B S T RACT To study the capacity for moderate endurance exercise and change in metabolic fuel utilization during adaptation to a ketogenic diet, six moderately obese, untrained subjects were fed a eucaloric, balanced diet (base line) for $2 \mathrm{wk}$, followed by $6 \mathrm{wk}$ of a protein-supplemented fast (PSF), which provided $1.2 \mathrm{~g}$ of protein $/ \mathrm{kg}$ ideal body wt, supplemented with minerals and vitamins. The mean weight loss was $10.6 \mathrm{~kg}$.
\end{abstract}

The duration of treadmill exercise to subjective exhaustion was $80 \%$ of base line after $1 \mathrm{wk}$ of the PSF, but increased to $155 \%$ after 6 wk. Despite adjusting up to base line, with a backpack, the subjects' exercise weight after $6 \mathrm{wk}$ of dieting, the final exercise test was performed at a mean of $60 \%$ of maximum aerobic capacity, whereas the base-line level was $76 \%$. Resting vastus lateralis glycogen content fell to $57 \%$ of base line after $1 \mathrm{wk}$ of the PSF, but rose to $69 \%$ after $6 \mathrm{wk}$, at which time no decrement in muscle glycogen was measured after $>4 \mathrm{~h}$ of uphill walking. The respiratory quotient $(\mathrm{RQ})$ during steady-state exercise was 0.76 during base line, and fell progressively to 0.66 after $6 \mathrm{wk}$ of the PSF. Blood glucose was well maintained during exercise in ketosis. The sum of acetoacetate and beta hydroxybutyrate rose from 3.28 to $5.03 \mathrm{mM}$ during exercise after $6 \mathrm{wk}$ of the PSF, explaining in part the low exercise $R Q$.

The low $\mathrm{RQ}$ and the fact that blood glucose and muscle glycogen were maintained during exhausting exercise after $6 \mathrm{wk}$ of a PSF suggest that prolonged ketosis results in an adaptation, after which lipid becomes the major metabolic fuel, and net carbo-

This work was presented in part at the Annual Meeting of the American Federation for Clinical Research, San Francisco, Calif., May 1978.

Address reprint requests to Dr. Edward S. Horton, Metabolic Unit, Department of Medicine, University of Vermont, Burlington, Vt. 05405.

Received for publication 6 June 1979 and in revised form 21 July 1980 hydrate utilization is markedly reduced during moderate but ultimately exhausting exercise.

\section{INTRODUCTION}

Previous studies have suggested that optimum function at high submaximal work loads for prolonged periods is best promoted by maximizing muscle glycogen content. This was based on the pioneering work of Christensen (1), who first demonstrated increased endurance as a result of taking a diet high in carbohydrate. Subsequently, Bergstrom and Hultman (2) and Hultman (3) correlated exhaustion with glycogen depletion in the exercising muscle and demonstrated increased muscle glycogen and increased endurance after consuming a high carbohydrate diet. Conversely, diets low in carbohydrate were found to be associated with reduced muscle glycogen and endurance. Multiple variables affect the rate of carbohydrate utilization by exercising muscle relative to that of free fatty acids (FFA), the other major energyyielding substrates. In particular, improved training by aerobic exercise and decreased work intensity both reduce the proportional oxidation of carbohydrate relative to fatty acids (4). Nonetheless, at high submaximal workloads and despite training, carbohydrate has been considered to be a required fuel.

This conclusion was reinforced by the study by Kark et al. (5) of Canadian Army troops during World War II. Under winter training conditions, the troops were abruptly switched from standard rations to an unsupplemented meat and fat pemmican preparation, which constituted their sole source of calories. Within $3 \mathrm{~d}$, this carbohydrate-free, salt-free, ketogenic diet reduced the men to nonfunctional status. The addition of carbohydrate and salt to the regimen brought about a rapid improvement in function.

The study by Kark et al. (5), as well as the one by Bergstrom and Hultman (2), used dietary periods of $10 \mathrm{~d}$ or less. That a longer period of adaptation might 
yield different results is suggested by the field observations of Stefansson (6). This anthropologist and arctic explorer lived for $10 \mathrm{yr}$ on the meat and fat diet of the Eskimo people, whom he studied early in this century. In a subsequent dietary study at the Russell Sage Unit at Bellevue Hospital, Stefansson and a companion consumed a similar diet of protein and fat for $1 \mathrm{yr}$. McClellan and DuBois (7), and McClellan et al. (8) reported that both subjects maintained weight, nitrogen balance, and normal functional status while in persistent ketosis for the full period. Though no formal studies of exercise were done, the authors noted that performance times in a 2.25-mile run at intervals during the initial 2 mo of the diet remained constant.

Although eucaloric, ketogenic diets such as those studied by McClellan and Kark have little clinical relevance at present, supplemented fasting has become a common practice in the treatment of severe obesity. This type of diet has particular relevance to obesity complicated by hypertension and/or diabetes, because the natriuretic effects of the supplemented fast frequently reduce or normalize blood pressure, and the associated reduced insulin requirement usually obviates the need for exogenous insulin in the type II obese noninsulin-dependent diabetic. Because physical training has been advanced to promote weight loss and reduce recidivism after weight loss programs, it is important to know whether ketosis impairs the capacity for endurance exercise. The studies cited above are contradictory on this point, and in any case, base their conclusions on studies with eucaloric diets. We have therefore studied the metabolic changes and capacity for endurance exercise in six moderately obese volunteers before and during a 6-wk course of protein-supplemented fasting (PSF). ${ }^{1}$

\section{METHODS}

Subjects. Six slightly to moderately overweight, untrained volunteers (five females, one male) were admitted to the Clinical Research Center of the University of Vermont College of Medicine for the 8-wk period of study. After receiving detailed explanation of all planned procedures, all subjects gave prior informed consent. Preadmission evaluation determined the following to be normal: complete physical examination, chest roentgenogram, ECG stress test, oral glucose tolerance test, complete blood count, serum electrolytes, renal and liver function parameters, uric acid, lipids, total protein, albumin, urinalysis, and negative urine pregnancy test. Characteristics of the six subjects are presented in Table I.

Diets. During an initial 2-wk base-line period, the subjects were fed a eucaloric diet providing $1,400 \mathrm{kcal} / \mathrm{m}^{2}$ formulated from common foods, containing $45 \%$ of energy as carbohydrate, $40 \%$ as fat, and $15 \%$ as protein. This diet was suc-

\footnotetext{
${ }^{1}$ Abbreviations used in this paper: PSF, protein-supplemented fast; $\mathrm{RQ}$, respiratory quotient; $\mathrm{rT}_{3}, 3,3^{\prime}, 5^{\prime}$-triiodothyronine; $T_{3}, 3,5,3^{\prime}$-triiodothyronine; $T_{4}$, thyroxine; $V_{O_{2} \max }$, maximum rate of oxygen uptake.
}

ceeded by a 6 -wk period during which the subjects ate a diet that consisted of lean meat, fish, or fowl, and provided $1.2 \mathrm{~g}$ protein $/ \mathrm{kg}$ ideal body wt per $\mathrm{d}$. This was supplemented by $25 \mathrm{meq} / \mathrm{d}$ of potassium as bicarbonate. Vitamins and iron were supplemented to meet the Recommended Daily Allowance (Fig. 1). Noncaloric beverages were allowed ad lib. above a mandatory minimum of $1,500 \mathrm{ml} / \mathrm{d}$. Food was salted to taste and extra sodium provided in the form of bouillon when necessary to prevent orthostatic symptoms.

Routine monitoring. Weight was measured daily. Blood pressure, pulse, respirations, temperature, and urine ketones (by Acetest tablet, Miles Laboratories, Inc., Elkhart, Ind.) were monitored twice daily. Blood was drawn biweekly for the following tests: whole blood for hemoglobin, hematocrit, leukocyte count, differential, platelet estimate, and erythrocyte indices; serum for sodium, potassium, chloride, bicarbonate, magnesium, calcium, phosphorus, uric acid, urea nitrogen, creatinine, albumin, total protein, total and direct bilirubin, serum aspartate aminotransferase, serum alanine aminotransferase, alkaline phosphatase, cholesterol, and triglycerides; heparinized plasma for prothrombin time and partial thromboplastin time; and oxalate/fluoride-treated plasma for glucose. Refrigerated, 24-h urine collections were analyzed for creatinine during weeks 1,4 , and 8 of the study.

The percentage of body fat was estimated during the baseline period and during the final week of the study by hydrostatic weighing (9).

Exercise testing. The maximum rate of oxygen uptake $\left(\mathrm{V}_{\mathrm{O}_{2} \max }\right)$ was determined for each subject after an overnight fast during the $2 \mathrm{nd}$ wk of the base-line period. Serial 3-min treadmill workbouts of increasing severity were interrupted by sufficient time to allow pulse to stabilize below 100 beats/ min and respiration to return to normal. Expired air was collected in Douglas bags during the final $60 \mathrm{~s}$ of each workbout, and the volume measured in a Tissot apparatus (Warren Collins Co., Braintree, Mass.) and corrected for temperature and barometric pressure. Aliquots of gas were immediately collected over mercury for carbon dioxide and oxygen determination by the Scholander method (10). $\mathrm{V}_{\mathrm{O}_{2} \max }$ was measured again in three subjects after $5 \mathrm{wk}$ of the PSF to rule out any major change during the period of weight loss.

Treadmill endurance of the subjects was measured during uninterrupted exercise after an overnight fast at the end of the base-line diet and twice more, after consuming the ketogenic diet for 1 and $6 \mathrm{wk}$. Treadmill speed and angle were adjusted to provide an estimated workload equal to $75 \%$ of each subject's tested base-line $\mathrm{V}_{\mathrm{O}_{2} \max }$, and was maintained the same for each subject in all three tests (see Table III). For the final endurance test, subjects carried a backpack adjusted in weight to compensate for weight lost during the $6 \mathrm{wk}$ of hypocaloric dieting.

Continuous ECG monitoring was performed for the duration of all tests. 60-s collections of expired gas were obtained in Douglas bags after $10 \mathrm{~min}$ and again just before termination of each test. Subjects were encouraged to remain on the treadmill until subjective exhaustion. Strenuous exercise was prohibited for the week before each endurance test, and subjects were instructed to maintain their usual levels of activity during the 8-wk study period to avoid any training effect.

Muscle glycogen. Percutaneous muscle biopsies were obtained from the vastus lateralis muscle $20-40 \mathrm{~min}$ before and 5-15 min after each treadmill endurance test. After local anesthesia, a $3.5-\mathrm{mm}$ Diam side-cutting needle was passed through a 5-mm skin incision and subcutaneous adipose tissue, and then advanced $\sim 3 \mathrm{~cm}$ beyond the muscle fascia. A single pass with the inner cutting cylinder yielded a mean of $17 \pm 8 \mathrm{mg}$ of muscle. The incision was closed with 
TABLE I

Subjects of Study

\begin{tabular}{cccccrc}
\hline Sex & Age & $\begin{array}{c}\text { Initial } \\
\text { weight }\end{array}$ & $\begin{array}{c}\text { Percent ideal } \\
\text { body weight }\end{array}$ & $\begin{array}{c}\text { Percent } \\
\text { fat }\end{array}$ & $\begin{array}{c}\text { Weight } \\
\text { loss }\end{array}$ & $\begin{array}{c}\text { Weight } \\
\text { loss fat }\end{array}$ \\
\hline & $y r$ & $k g$ & & & $k g$ & $k g$ \\
F & 30 & 95.9 & 172 & 45.0 & 11.9 & 8.0 \\
F & 21 & 74.5 & 118 & 34.6 & 9.5 & 7.3 \\
F & 22 & 81.5 & 125 & 30.8 & 9.6 & 5.3 \\
F & 23 & 96.4 & 148 & 38.9 & 11.0 & 7.3 \\
F & 25 & 92.2 & 165 & 42.4 & 10.9 & 7.0 \\
M & 38 & 98.1 & 123 & 26.2 & 10.9 & 8.0 \\
Mean \pm SEM & $26.5 \pm 2.6$ & $89.8 \pm 3.9$ & $142 \pm 9$ & $36.3 \pm 2.9$ & $10.6 \pm 0.4$ & $7.1 \pm 0.4$ \\
\hline
\end{tabular}

The percent ideal body weight was calculated from each subject's initial weight and the ideal weight for height determined from Metropolitan Life Insurance Company tables for medium-frame individuals. Initial percent body fat and fat loss were calculated from measurements of body density.

adhesive tape, and a pressure dressing and ice were applied. The muscle tissue was rapidly dissected free from visible connective tissue and fat. Samples were suspended from a stainless steel wire attached to the enclosed weighing arm of a Mettler balance (Mettler Instrument Corp., Hightstown, N. J.) and weighed at timed intervals for 2-3 min. Initial weights were calculated by extrapolation to time zero when the sample was removed from the needle. The tissue was solubilized with warming in $30 \% \mathrm{KOH}$, glycogen was precipitated with iced ethanol and hydrolyzed in $6 \mathrm{~N} \mathrm{H}_{2} \mathrm{SO}_{4}$, and the released glucose was determined colorimetrically with ortho-toludine.

Pre-and postexercise blood analyses. Immediately before each endurance test, peripheral blood was drawn with minimal hemostasis from the fasted subjects after they had rested in the supine position for $20 \mathrm{~min}$. Studies included spun hematocrit, blood lactate, pyruvate, beta hydroxybutyrate, acetoacetate, and glycerol; serum total protein, thyroxine $\left(T_{4}\right), 3,5,3^{\prime}$-triiodothyronine $\left(T_{3}\right)$, and 3,3',5'-triiodothyronine $\left(\mathrm{rT}_{3}\right)$; and plasma glucose, FFA, insulin, glucagon, and growth hormone. The same determinations were then repeated immediately after exercise $(3-6 \mathrm{~min})$, and again after the subjects had rested in the supine position for $20 \mathrm{~min}$.

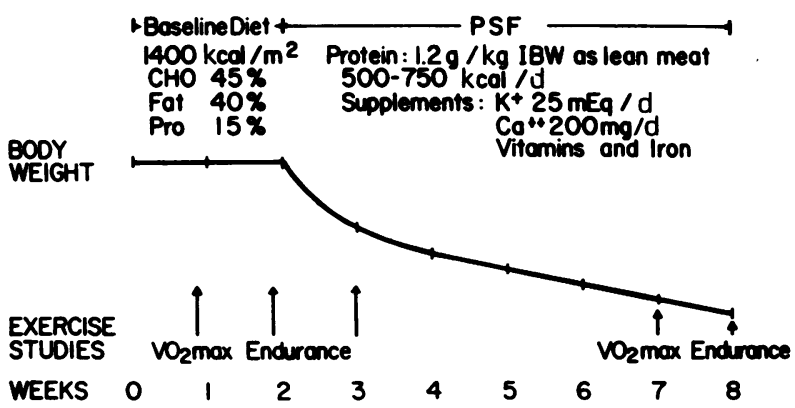

FIGURE 1 Study protocol. The base-line diet consisted of normal foods with calories adjusted to maintain constant body weight. The PSF consisted of lean meat supplemented with vitamins and minerals. The daily protein intake was $1.2 \mathrm{~g} / \mathrm{kg}$ ideal body wt (determined from Metropolitan Life Insurance Company tables for medium-frame individuals).
Plasma insulin and growth hormone were measured by a double-antibody immunoassay method using ${ }^{125}$ I-labeled pork insulin and human growth hormone as tracers, and human insulin (516-734B-33, Eli Lilly \& Co., Indianapolis, Ind.) and growth hormone (H.S.2160E, National Pituitary Agency, Bethesda, Md.) standards (11). Plasma glucagon was measured by a double-antibody immunoassay method using ${ }^{125}$ I-glucagon purchased from Nuclear Medical Laboratories, Inc., Dallas, Tex., antiglucagon serum 30K (Roger Unger, University of Texas [S. W.], Dallas, Tex.), and porcine glucagon standards (Eli Lilly \& Co.). Blood specimens were collected in the presence of a kallikrein inhibitor (Trasylol, FBA Pharmaceuticals, New York, N. Y.), $500 \mathrm{U} / \mathrm{ml}$, to retard degradation of glucagon.

$\mathrm{T}_{3}, \mathrm{rT}_{3}$, and $\mathrm{T}_{4}$ were determined by radioimmunoassay (12). Because the thyroid hormones are predominantly bound to serum proteins (99\%), including albumin, prealbumin, and thyroid-binding globulins, and because endurance exercise is associated with significant hemoconcentration, all values of these hormones have been normalized to $8.0 \mathrm{~g} / \mathrm{dl}$ protein to correct for the changes in serum protein concentrations that took place during exercise. Total serum protein was determined by a microbiuret technique (13). Specimens for hormone and protein determinations were stored at $-20^{\circ} \mathrm{C}$ before analysis.

Lactate, pyruvate, beta hydroxybutyrate, acetoacetate, and glycerol were determined on protein-free filtrates obtained by adding blood to an equal volume of iced $30 \%$ perchloric acid and mixing immediately. After separation in a refrigerated centrifuge, the supernates were frozen and stored at $-20^{\circ} \mathrm{C}$ until used for analyses. The assays were modifications of enzymatic methods described by Bergmeyer (14) using an American Instrument Company Fluoro-colorimeter (American Instrument Co., Travenol Laboratories Inc., Silver Spring, Md.) to record changes in NADH concentrations. Plasma FFA were determined by the colorimetric method of Novak (15). Plasma glucose was measured by a glucose oxidase method with a Yellow Springs Instruments model 23A analyzer (Yellow Springs Instrument Co., Yellow Springs, Ohio).

Statistics. Data are reported \pm SEM. Studies yielding one value per test period (exercise duration, percent $V_{\mathbf{O}_{2 m a x}}$, pulse rate, and respiratory quotient (RQ), which the overall study was designed to compare, were analyzed by one-way analysis of variance, with intervalue significance determined by the Least Significant Differences test (16). 
Blood substrate and hormone data were assessed by repeated measures of analysis of variance. Where multiple comparisons were performed, the Newman-Keuls test was used as a more rigorous test of significance. To make maximum use of available data, the analysis of variance for the glycogen results was done by the TANVAR program of the PROPHET system (see Acknowledgments), which accepts missing data points.

\section{RESULTS}

All six subjects maintained excellent health and function for the 8-wk duration of the study. Except for minor blisters and chafing, there were no complications from the exercise testing or muscle biopsy procedures.

Diet effects. Following an initial adjustment period of $3 \mathrm{~d}$, all subjects maintained stable weight while taking the eucaloric base-line diet of $1,400 \mathrm{kcal} / \mathrm{m}^{2}$. With initiation of the ketogenic diet, there was an early diuresis with associated brisk weight loss, followed by a uniform loss of $\sim 0.35 \mathrm{~kg} / \mathrm{d}$ (see Table I). Adherence to the diet was excellent, as judged by the uniformity of weight loss and persistent urinary ketones observed twice daily in all subjects beginning 24-48 $\mathrm{h}$ after starting the PSF. By comparing initial and final determinations of body composition by hydrostatic weighings, $7.1 \mathrm{~kg}(67 \%)$ of the $10.6 \mathrm{~kg}$ mean weight loss was fat. Mean 24-h urinary creatinine excretion decreased insignificantly from $1.73 \pm 0.15 \mathrm{~g}$ during base line to $1.69 \pm 0.13 \mathrm{~g}$ after $1 \mathrm{wk}$ and $1.68 \pm 0.14 \mathrm{~g}$ after 6 wk of the PSF.

Hematological, electrolyte, lipid, hepatic function, and renal function monitoring. The complete blood count, serum sodium, magnesium, calcium, potassium, chloride, phosphate, bilirubin, albumin, alkaline phosphatase, urea, and creatinine remained within normal limits for all subjects for the duration of the study. The serum alanine aminotransferase remained normal in four subjects, and was minimally elevated in the other two; all other tested parameters of the liver function in the subjects remained normal. The mean serum uric acid was $5.0 \pm 0.4 \mathrm{mg} / \mathrm{dl}$ during base-line

TABLE II

Maximum Oxygen Uptake and Response to Endurance Exercise

\begin{tabular}{|c|c|c|c|c|c|c|c|c|c|c|}
\hline \multirow[b]{2}{*}{ Subject } & \multirow[b]{2}{*}{$\dot{V}_{0_{\text {manax }}}$} & \multicolumn{7}{|c|}{ Treadmill endurance test } & \multicolumn{2}{|c|}{ Muscle glycogen } \\
\hline & & Speed & Grade & Pulse & Duration & - & $v_{0_{\max }}$ & RQ & $\begin{array}{c}\text { Before } \\
\text { exercise }\end{array}$ & $\begin{array}{c}\text { After } \\
\text { exercise }\end{array}$ \\
\hline & $\mathrm{ml} / \min$ & $m p h$ & $\%$ & beats/min & $\min$ & $\operatorname{ml} / \min$ & $\%$ & & $\mathrm{mg} / 100$ & wet wt \\
\hline \multicolumn{11}{|l|}{ Base line } \\
\hline C.D. & 2,352 & 3 & 8 & 165 & 80 & 2,087 & 89 & 0.78 & 1.73 & 1.23 \\
\hline M.W. & 2,494 & 3 & 10 & 171 & 107 & 1,774 & 71 & 0.73 & 1.55 & - \\
\hline D.M. & 2,101 & 3 & 10 & 167 & 197 & 1,506 & 72 & 0.74 & 1.41 & 1.02 \\
\hline H.L. & 3,547 & 3 & 14 & 157 & 186 & 2,506 & 71 & 0.87 & 1.68 & 1.65 \\
\hline P.C. & 2,217 & 3 & 4 & 173 & 184 & 1,626 & 73 & 0.70 & 1.26 & 1.28 \\
\hline R.T. & 2,228 & 3 & 8 & 183 & 253 & 1,752 & 79 & 0.72 & - & 1.27 \\
\hline Mean \pm SEM & $2,490 \pm 218$ & & & $169 \pm 4$ & $168 \pm 26$ & $1,875 \pm 149$ & $75 \pm 3$ & $0.76 \pm 0.3$ & $1.53 \pm 0.09$ & $1.29 \pm 0.10$ \\
\hline \multicolumn{11}{|l|}{ PSF 1 wk } \\
\hline C.D. & & 3 & 8 & 150 & 47 & & & & 1.13 & 0.97 \\
\hline M.W. & & 3 & 10 & 167 & 122 & 1,489 & 60 & 0.64 & 0.46 & 0.58 \\
\hline D.M. & & 3 & 10 & 158 & 156 & 1,306 & 62 & 0.72 & 1.16 & 0.78 \\
\hline H.L. & & 3 & 14 & 163 & 129 & 2,820 & 80 & 0.93 & 1.13 & 0.89 \\
\hline P.C. & & 3 & 4 & 164 & 180 & 1,186 & 54 & 0.64 & 0.72 & 0.96 \\
\hline R.T. & & 3 & 8 & 180 & 147 & 1,768 & 79 & 0.68 & 0.63 & 0.40 \\
\hline Mean \pm SEM & & & & $164 \pm 4$ & $130 \pm 9$ & $1,714 \pm 293$ & $69 \pm 5$ & $0.72 \pm 0.05$ & $0.87 \pm 0.12$ & $0.76 \pm 0.09$ \\
\hline \multicolumn{11}{|l|}{ PSF 6 wk } \\
\hline C.D. & 2,313 & 3 & 8 & 151 & 144 & 1,666 & 71 & 0.68 & 0.73 & 0.84 \\
\hline M.W. & & 3 & 10 & 127 & 201 & 1,490 & 60 & 0.64 & 1.11 & 1.10 \\
\hline D.M. & & 3 & 10 & 146 & 320 & 1,234 & 59 & 0.67 & 1.10 & 0.73 \\
\hline H.L. & & 3 & 14 & 138 & 260 & 1,996 & 56 & 0.74 & 1.13 & 1.32 \\
\hline P.C. & 2,626 & 3 & 4 & 136 & 248 & 1,225 & 55 & 0.62 & 1.12 & 1.06 \\
\hline R.T. & 2,422 & 3 & 8 & & 322 & 1,369 & 61 & 0.62 & 1.08 & 1.08 \\
\hline Mean \pm SEM & $2,454 \pm 91$ & & & $140 \pm 4$ & $249 \pm 28$ & $1,497 \pm 121$ & $60 \pm 1$ & $0.66 \pm 0.02$ & $1.04 \pm 0.06$ & $1.02 \pm 0.08$ \\
\hline
\end{tabular}

Abbreviations used in this table: $V_{0_{2}}$, oxygen uptake during steady-state exercise; $V_{0_{2} \max }$, maximum oxygen uptake; $R Q$, respiratory exchange ratio during steady-state exercise; before exercise, 20-40 min before exercise; after exercise, 5-15 min after exercise. 
diet, rose to $9.7 \pm 0.5 \mathrm{mg} / \mathrm{dl}$ after $2 \mathrm{wk}$ of the PSF, and declined to $5.9 \pm 0.7 \mathrm{mg} / \mathrm{dl}$ after $6 \mathrm{wk}$ of the PSF. Serum cholesterol decreased significantly from 186 \pm 11 to $147 \pm 7 \mathrm{mg} / \mathrm{dl}(P<0.01)$ and triglycerides went from $104 \pm 17$ to $79 \pm 11 \mathrm{mg} / \mathrm{dl}$ after 6 wk of the supplemented fast.

Endurance exercise capacity and respiratory gas analysis. The results of the $\mathrm{V}_{\mathrm{O}_{2} \max }$ and endurance testing are presented in Table II. The $\mathrm{V}_{\mathrm{O}_{2} \max }$ data are further summarized in Table III. The initial mean $\mathrm{V}_{\mathrm{O}_{2} \max }$ of $27.7 \pm 2.3 \mathrm{ml} / \mathrm{kg}$ per min for the six subjects was comparable to that found in physically untrained individuals (17). The repeat values (for three subjects) of the $\mathrm{V}_{\mathrm{O}_{2} \max }$ (Table III) reveal a slight, statistically insignificant increase after $5 \mathrm{wk}$ of the PSF.

With one exception, the subjects were free of focal muscle, joint, or cardiopulmonary complaints during all stages of testing. The reason for termination of the endurance test was always generalized exhaustion. The only exception to this occurred during the second endurance test, when subject C.D. felt early initial fatigue and shortness of breath, and had premature ventricular contractions. The exercise test was terminated immediately, and sinus rhythm rapidly returned to normal. Subsequent electrocardiograms were completely normal, and this subject's final exercise test after $6 \mathrm{wk}$ of the PSF was performed without arrhythmia or incident.

The base-line endurance test was performed with a mean work load of $76 \pm 3 \%$ of $\mathrm{V}_{\mathrm{O}_{2} \max }$, a mean heart rate of $166 \pm 4$ beats $/ \mathrm{min}$, and an $R Q$ of $0.76 \pm 0.03$. The mean time to subjective exhaustion was $168 \pm 26 \mathrm{~min}$.

During the endurance test after 1 wk of the PSF, mean oxygen consumption was slightly lower (67 $\pm 5 \%$ of $\left.\mathrm{V}_{\mathrm{O}_{2} \max }\right)$, mean heart rate was correspondingly less at $164 \pm 4$ beats/min, the mean $R Q$ was 0.72 , and the subjects mean weight was $3 \mathrm{~kg}$ less than during

TABLE III

Maximum Oxygen Uptake

\begin{tabular}{cccc}
\hline Diet & \multicolumn{3}{c}{$\mathrm{V}_{\mathrm{O}_{\text {max }}}$} \\
\hline & liters/min & ml/kg/min & $\begin{array}{c}\text { ml/kg lean } \\
\text { body mass/min }\end{array}$ \\
Base-line $(n=6)$ & $2.49 \pm 0.22$ & $27.7 \pm 2.3$ & $43.6 \pm 2.4$ \\
Base-line $(n=3)$ & $2.31 \pm 0.09$ & $26.8 \pm 3.4$ & $43.6 \pm 4.1$ \\
PSF 5 wk $(n=3)$ & $2.45 \pm 0.09$ & $31.5 \pm 3.4$ & $48.8 \pm 1.0$ \\
\hline
\end{tabular}

$\mathrm{V}_{\mathrm{O}_{2} \text { max }}$ was determined by the Scholander technique from collections of expired gas made during the 3rd min of intermittent periods of treadmill exercise of increasing intensity until maximum effort was reached. $V_{O_{2} \max }$ was taken as the highest rate of oxygen uptake observed under these conditions. Values are means \pm SEM for all subjects during the base-line diet period and for three subjects studied during the base-line period and again after $5 \mathrm{wk}$ of the PSF. Lean body mass was estimated from body weight and density. the base-line test. Despite the slightly lower workload, endurance time was decreased to $130 \pm 19 \mathrm{~min}$, or $79.5 \%$ of the base-line value.

In contrast, the final endurance test, conducted after $6 \mathrm{wk}$ on the ketogenic diet, resulted in a mean endurance time of $249 \pm 28 \mathrm{~min}$, an increase to $155 \%$ of base line and $192 \%$ of the 1 -wk value $(P<0.01)$. One possible factor in the increased endurance is that, despite the equalization of weight by backpack and utilization of identical treadmill grade and speed, this test was performed at an even lower mean oxygen consumption $\left(60 \pm 2 \%\right.$ of $\left.\mathrm{V}_{\mathrm{O}_{2} \max }, P<0.05\right)$, with a similarly lowered mean heart rate of $140 \pm 4(P<0.01)$. The mean $R Q$ during this test was $0.66 \pm 0.02$. The progressive fall in the exercise $R Q$ over the three test periods is significant at $P<0.001$.

Glycogen content of muscle. The mean resting glycogen content of the vastus lateralis after $2 \mathrm{wk}$ of the base-line diet was $1.53 \pm 0.09 \mathrm{~g} / 100 \mathrm{~g}$ wet wt muscle, which is in the normal range for subjects consuming this type of diet (3). After exercise to exhaustion, the mean glycogen content of the same muscle was reduced to $1.29 \pm 0.10 \mathrm{~g} / 100 \mathrm{~g}$ wet wt tissue. The respective pre- and postexercise glycogen contents after $1 \mathrm{wk}$ of the PSF were $0.87 \pm 0.12$ and $0.76 \pm 0.09 \mathrm{~g}$. Both are significantly lower than the respective pre- and postexercise levels observed during base line. After 6 $w k$, the resting glycogen content had risen to 1.05 $\pm 0.06 \mathrm{~g}$, but was still significantly less $(P<0.01)$ than the preexercise value during the base-line diet. Despite $>4 \mathrm{~h}$ of exercise at $60 \%$ of $\mathrm{V}_{\mathrm{O}_{2} \max }$, muscle glycogen content remained constant at $1.02 \pm 0.08 \mathrm{~g}$. Although, as noted above, the 1 - and 6-wk resting glycogen values are both significantly less than base line, neither the exercise-induced fall at base line or $1 \mathrm{wk}$, nor the rise in the resting value from 1 to $6 \mathrm{wk}$ of the PSF achieves significance.

Blood substrate response to diet and exercise. The data for blood, lactate, pyruvate, beta hydroxybutyrate, acetoacetate, glycerol, plasma FFA, and glucose are presented in Table IV. The mean fasting blood glucose level at rest decreased from $89.2 \pm 1.6 \mathrm{mg} / \mathrm{dl}$ during the base-line period to $74.7 \pm 2.2 \mathrm{mg} / \mathrm{dl}$ after $6 \mathrm{wk}$ of the supplemented fast $(P<0.05)$. The effects of exhaustive exercise on plasma glucose, measured 3-6 min after cessation of exercise, were mean reductions of $2.0 \mathrm{mg} / \mathrm{dl}$ during the base-line period, $5.0 \mathrm{mg} / \mathrm{dl}$ after $1 \mathrm{wk}$, and $1.4 \mathrm{mg} / \mathrm{dl}$ after $6 \mathrm{wk}$ of the PSF. There were further decreases in the 20-min postexercise values in all three exercise tests. No subject developed symptoms of hypoglycemia during exercise, and the lowest glucose level observed was $56 \mathrm{mg} / \mathrm{dl}$.

After $1 \mathrm{wk}$ of the PSF, the resting concentration of blood pyruvate was reduced $(P<0.05)$, but lactate was unchanged. After $6 \mathrm{wk}$ both the lactate $(P<0.005)$ and pyruvate $(P<0.01)$ concentrations were signifi- 
TABLE IV

Substrate Concentrations in Whole Blood or Plasma during Endurance Exercise Tests

\begin{tabular}{|c|c|c|c|c|c|c|c|}
\hline & Glucose & Lactate & Pyruvate & $\begin{array}{c}\text { 3-OH } \\
\text { Butyrate }\end{array}$ & $\begin{array}{l}\text { Aceto- } \\
\text { acetate }\end{array}$ & FFA & Glycerol \\
\hline & mg/dl & & & $m M$ & & & \\
\hline \multicolumn{8}{|l|}{ Base line } \\
\hline Resting & $89.2 \pm 1.6$ & $0.70 \pm 0.04$ & $0.064 \pm 0.004$ & $0.06 \pm 0.02$ & $0.02 \pm 0.00$ & $0.71 \pm 0.08$ & $0.21 \pm 0.03$ \\
\hline 3-6 $\mathrm{min}$ postexercise & $87.2 \pm 4.4$ & $1.51 \pm 0.16$ & $0.116 \pm 0.014$ & $0.45 \pm 0.11$ & $0.11 \pm 0.02$ & $2.24 \pm 0.23$ & $0.89 \pm 0.12$ \\
\hline 20 min postexercise & $83.8 \pm 2.4$ & $1.44 \pm 0.19$ & $0.092 \pm 0.012$ & $0.71 \pm 0.13$ & $0.14 \pm 0.02$ & $2.32 \pm 0.17$ & $0.64 \pm 0.11$ \\
\hline \multicolumn{8}{|l|}{ PSF 1 wk } \\
\hline Resting & $74.5 \pm 3.2$ & $0.68 \pm 0.07$ & $0.046 \pm 0.005$ & $2.30 \pm 0.51$ & $0.43 \pm 0.06$ & $1.22 \pm 0.12$ & $0.23 \pm 0.02$ \\
\hline 3-6 min postexercise & $69.5 \pm 2.7$ & $1.61 \pm 0.10$ & $0.148 \pm 0.022$ & $2.56 \pm 0.58$ & $0.67 \pm 0.13$ & $3.38 \pm 0.11$ & $1.26 \pm 0.14$ \\
\hline $20 \mathrm{~min}$ postexercise & $65.7 \pm 1.6$ & $1.33 \pm 0.09$ & $0.109 \pm 0.017$ & $3.02 \pm 0.49$ & $0.69 \pm 0.09$ & $3.18 \pm 0.12$ & $0.91 \pm 0.15$ \\
\hline \multicolumn{8}{|l|}{ PSF 6 wk } \\
\hline Resting & $74.7 \pm 2.2$ & $0.56 \pm 0.02$ & $0.036 \pm 0.003$ & $2.73 \pm 0.33$ & $0.54 \pm 0.04$ & $1.11 \pm 0.21$ & $0.24 \pm 0.00$ \\
\hline 3-6 $\mathrm{min}$ postexercise & $73.3 \pm 5.0$ & $1.71 \pm 0.18$ & $0.146 \pm 0.022$ & $3.77 \pm 0.56$ & $1.11 \pm 0.15$ & $3.13 \pm 0.13$ & $1.00 \pm 0.09$ \\
\hline $20 \mathrm{~min}$ postexercise & $70.0 \pm 4.8$ & $1.41 \pm 0.16$ & $0.091 \pm 0.013$ & $4.17 \pm 0.57$ & $1.04 \pm 0.15$ & $3.08 \pm 0.15$ & $0.76 \pm 0.07$ \\
\hline
\end{tabular}

Concentrations of glucose and FFA were determined in plasma. The remaining substrates were determined in perchloric acid filtrates of whole blood. Resting values were obtained after an overnight fast before exercise, and the 3-6-min and 20-min postexercise values were obtained with the subjects resting quietly after cessation of exercise to subjective exhaustion. Values are the means \pm SEM for the six subjects.

cantly decreased at rest. No significant differences were seen after exercise, however, as both substrates exhibited similar patterns and magnitudes of elevation in all three phases of endurance exercise testing. Resting concentrations of acetoacetate and beta hydroxybutyrate both rose sharply in the lst wk of the ketogenic diet $(P<0.05)$, with a further slight rise after 6 wk. In all phases of the study, the mean combined ketone concentration rose with exercise, and continued to increase $20 \mathrm{~min}$ into the postexercise period (Courtice-Douglas effect). The resting FFA concentration after an overnight fast was increased after 1 wk of the PSF $(P<0.05)$ and remained elevated at $6 \mathrm{wk}$. FFA rose immediately after exercise in all test periods, but achieved higher 3-6-min postexercise levels during the ketogenic diet than during base line $(P$
$<0.01$ ). Despite the changes in fasting FFA, there was no significant change in fasting glycerol concentrations with change in diet. The rise in glycerol with exercise was greatest after $1 \mathrm{wk}$ of the PSF, returning toward the base-line values after 6 wk. This apparent normalization of glycerol occurred despite nearly equal postexercise elevations of FFA concentration after 1 and $6 \mathrm{wk}$ on the ketogenic diet.

Hormone responses to diet and exercise. The insulin, glucagon, and growth hormone data are presented in Table $V$. The fasting insulin after $1 \mathrm{wk}$ of the carbohydrate-free PSF fell from $7.5 \pm 0.8$ to $2.7 \pm 0.8 \mu \mathrm{U} / \mathrm{ml}$ and remained low at $3.2 \pm 0.9 \mu \mathrm{U} / \mathrm{ml}$ after $6 \mathrm{wk}$. There were sharp increases $(1 \mathrm{wk}, P<0.01$; $6 \mathrm{wk}, P<0.05)$ in insulin concentration in the postexercise period. Though reaching the same magnitude

TABLE V

Hormone Concentrations in Plasma during Endurance Exercise Tests

\begin{tabular}{|c|c|c|c|c|c|c|c|}
\hline & Insulin & Glucagon & Growth hormone & $\mathrm{T}_{4}$ & $T_{3}$ & $\mathrm{rT}_{3}$ & Serum protein \\
\hline & $\mu U / m l$ & $p g / m l$ & $n g / m l$ & $\mu g / d l$ & $n g / d l$ & $n g / d l$ & g/dl \\
\hline \multicolumn{8}{|l|}{ Base line } \\
\hline Resting & $7.5 \pm 0.8$ & $197 \pm 16$ & $2.2 \pm 1.2$ & $8.0 \pm 0.2$ & $157 \pm 6$ & $29 \pm 1$ & $8.5 \pm 0.2$ \\
\hline $3-6 \mathrm{~min}$ postexercise & $11.7 \pm 3.7$ & $414 \pm 104$ & $7.2 \pm 5.0$ & $8.4 \pm 0.3$ & $144 \pm 3$ & & $9.3 \pm 0.2$ \\
\hline $20 \mathrm{~min}$ postexercise & $14.5 \pm 4.0$ & $370 \pm 72$ & $1.7 \pm 0.8$ & $8.7 \pm 0.1$ & $143 \pm 5$ & & $8.8 \pm 0.2$ \\
\hline \multicolumn{8}{|l|}{ PSF 1 wk } \\
\hline Resting & $2.7 \pm 0.8$ & $252 \pm 17$ & $2.2 \pm 0.8$ & $8.2 \pm 0.3$ & $105 \pm 3$ & $50 \pm 4$ & $8.4 \pm 0.2$ \\
\hline 3-6 min postexercise & $13.5 \pm 3.0$ & $522 \pm 71$ & $3.8 \pm 1.9$ & $9.1 \pm 0.4$ & $103 \pm 3$ & & $9.2 \pm 0.3$ \\
\hline 20 min postexercise & $13.8 \pm 3.1$ & $432 \pm 36$ & $2.6 \pm 1.6$ & $9.1 \pm 0.3$ & $95 \pm 3$ & & $8.7 \pm 0.2$ \\
\hline \multicolumn{8}{|l|}{ PSF 6 wk } \\
\hline Resting & $3.2 \pm 0.9$ & $217 \pm 19$ & $3.0 \pm 1.8$ & $7.2 \pm 0.7$ & $94 \pm 5$ & $41 \pm 2$ & $7.6 \pm 0.2$ \\
\hline $3-6$ min postexercise & $5.8 \pm 2.2$ & $357 \pm 33$ & $0.68 \pm 0.26$ & $7.6 \pm 0.4$ & $90 \pm 6$ & & $8.7 \pm 0.2$ \\
\hline 20 min postexercise & $11.3 \pm 3.6$ & $363 \pm 33$ & $0.30 \pm 0.07$ & $7.6 \pm 0.4$ & $86 \pm 6$ & & $8.1 \pm 0.1$ \\
\hline
\end{tabular}

Resting values were obtained from supine subjects after an overnight fast before exercise, and the 3-6-min and 20-min postexercise values were obtained with the subjects resting quietly following cessation of exercise to subjective exhaustion. The concentrations of $T_{4}$, $T_{3}$, and $r T_{3}$ have been adjusted to a serum protein concentration of $8.0 \mathrm{~g} / \mathrm{dl}$. Values are the means \pm SEM for the six subjects. 
after $20 \mathrm{~min}$, this rise appeared somewhat delayed after 6 wk of the PSF.

The fasting glucagon concentration rose from 197 \pm 16 to $252 \pm 17 \mathrm{pg} / \mathrm{ml}$ with initiation of the hypocaloric ketogenic diet and returned toward base line after $6 \mathrm{wk}$. Similarly, the glucagon response to exercise appeared accentuated after 1 wk of the PSF, while base-line concentrations were reached after $6 \mathrm{wk}$. The resting growth hormone concentration during the base-line period was $2.2 \mathrm{ng} / \mathrm{ml}$ and showed no response to change in the diet. There was, however, a progressive loss of response to exercise with increasing time on the PSF.

Serum concentrations of $\mathrm{T}_{3}$ in fasting subjects at rest decreased $33 \%(P<0.001)$, and $\mathrm{rT}_{3}$ increased $72 \%$ $(P<0.01)$ after $1 \mathrm{wk}$ of the diet (Table V). The further decrease in resting $T_{3}$ levels from 1 to $6 \mathrm{wk}$ of the hypocaloric diet did not represent a significant change, remaining below base line $(P<0.001)$. The resting $\mathrm{rT}_{3}$ levels, on the other hand, returned toward base line after $6 \mathrm{wk}$ of the diet. $\mathrm{T}_{4}$ concentrations were unaffected after $1 \mathrm{wk}$, but showed a slight though insignificant fall after $6 \mathrm{wk}$ of the diet.

Exercise during the base-line diet caused a fall in serum $\mathrm{T}_{3}$ concentrations $(P<0.001)$; and after both 1 and $6 \mathrm{wk}$ of the ketogenic diet, exercise accentuated the diet-induced decrease in $T_{3}$ concentrations. The exercise-induced rise in $\mathrm{T}_{4}$ levels was observed at all three testing times, but achieved significance ( $P$ $<0.05$ ) only after $1 \mathrm{wk}$ of the ketogenic diet.

\section{DISCUSSION}

The most important finding of this study is that prolonged exercise at $60 \%$ of $\mathrm{V}_{\mathrm{O}_{2} \max }$ can be sustained after the virtual absence $(<10 \mathrm{~g} / \mathrm{d})$ of dietary carbohydrate for $6 \mathrm{wk}$. The explanation appears to be a shift from the systemic utilization of carbohydrate as an energy-yielding substrate to lipid as the major source of energy for sustained exercise, as evidenced by an $\mathrm{RQ}$ of 0.66 during exercise, and a stable glycogen concentration in a muscle directly involved in (but probably not limiting) the exercise. This is in contrast to previous observations that glycogen is used at an appreciable rate by exercising skeletal muscle at submaximal work loads (2).

Although the final exercise test was performed at a lower percentage of the $\mathrm{V}_{\mathrm{O}_{2} \max }$, which itself should reduce the rate of glycogen depletion, a further explanation of this contradiction may lie in the length of the period of adaptation to ketosis allowed before exercise testing. The duration of endurance exercise was reduced to $80 \%$ of base line after $1 \mathrm{wk}$ of the ketogenic diet, and the timing of this phenomenon concurs with the observations of decreased endurance during ketosis made by previous investigators $(2,5$,
$18,19)$. The apparent rebound in the exercise time to $155 \%$ of base line after $6 \mathrm{wk}$ of ketosis was unanticipated because previous studies had rarely extended beyond $10 \mathrm{~d}$. The major exception to this was McClellan's (7) study of the arctic explorers, Stefansson and Anderson, the results of which have escaped mention in the recent literature. Also, Apfelbaum et al. (20) found that after $3 \mathrm{wk}$, grip strength and fatigability of grip were not diminished in healthy obese women given a daily diet of $50 \mathrm{~g}$ of casein.

Further evidence for an adaptation to ketosis was found in the change in exercise RQ with time, as well as the variations in muscle glycogen and blood substrates before and after exercise. The mean exercise $\mathrm{RQ}$ underwent a significant $(P<0.001)$, progressive decrease from base line to the 1- and 6-wk testing intervals. The resting muscle glycogen fell to $57 \%$ of the base-line value after $1 \mathrm{wk}$ of the PSF, and decreased further with exercise. After 6 wk, however, there was a partial reaccumulation of glycogen to $68 \%$ of base line, and the lack of decrement during exercise indicated no net utilization as substrate. Similarly, though resting blood glucose was reduced to the same degree after 1 and $6 \mathrm{wk}$ of the ketogenic diet, there was a smaller decrement with exercise after $6 \mathrm{wk}$. These data suggest that a period of adaptation $>1 \mathrm{wk}$ was required, during which both glucose and glycogen oxidation were progressively reduced during moderate exercise.

The metabolic control of this adaptation is not obvious. There was an early decline of the fasting insulin concentration, reaching a low level after the lst wk of the PSF and remaining low after $6 \mathrm{wk}$. The blunted insulin response to exercise after 6 wk could be a factor in the metabolic adaptation to this diet, as could the return of the pre- and postexercise glucagon to baseline values at this time. Another possible factor in the adaptation may be a decrease in glucose oxidation secondary to the oxidation of FFA and ketone bodies as proposed by Randle et al. (21).

It is apparent that the availability of FFA and ketones were not the only determinants of this fasting adaptation, as the former peaked in the lst wk and the latter had achieved $84 \%$ of the eventual 6 th-wk concentration by that time. Although production and metabolic clearance rates were not measured in this study, it is interesting to note the apparently greater rise of total ketones in exercise after $6 \mathrm{wk}$ than after $1 \mathrm{wk}$ of adaptation. This occurred without a similar increase of the FFA with exercise. This is in accord with the observations of Owen and Reichard (22), that prolonged starvation results in decreased skeletal muscle oxidation of ketones at rest, and similar observations by Haganfeldt and Wahren (23) regarding exercise, and suggests that in the present study, beta hydroxybutyrate and acetoacetate were reduced in significance 
as muscle substrates after $6 \mathrm{wk}$. One must then conclude that the FFA assumed an increasing role as substrate for exercising muscle as adaptation occurred. This is certainly compatible with the observed exercise $\mathrm{RQ}$, which fell progressively to a low at $6 \mathrm{wk}$.

The low RQ value of 0.66 observed during the final exercise test was surprising, as long-chain fatty acid oxidation occurs at an $R Q$ of 0.69 . (The only common fuel oxidized at a lower ratio is ethanol at 0.67.) The answer to this disparity may lie, at least in part, in the rise in serum ketone concentration observed during exercise. As the hepatic production of ketones from long-chain fatty acids occurs at an RQ of zero, a net retention of ketones in body fluids will result in a reduction in observed $R Q$ due to nonsteady-state conditions. By calculating the increase in the whole body ketone pool associated with exercise, one can account for approximately half of the decrement of $\mathrm{CO}_{2}$ production that would be necessary to explain the decrease in $\mathrm{RQ}$ below 0.69 . Other factors that could contribute to this low $R Q$ include losses of ketones in the urine and loss of acetone in the breath after decarboxylation of acetoacetate in the blood, as well as $\mathrm{CO}_{2}$ utilized in ureagenesis.

Another observation requiring explanation is the lack of a greater depletion of muscle glycogen with exhaustion, both during base-line testing and after $1 \mathrm{wk}$ of the hypocaloric ketogenic diet. Although nearly complete quadriceps femoris depletion is common with exhaustion from peddling a cycle ergometer at high submaximal workloads, this is not the case when walking or running on a treadmill (24). Costill et al. (25) noted an increased rate of removal of the vastus lateralis glycogen in uphill compared with level running, but complete utilization of glycogen was not achieved. Rather, exhaustion appeared to occur with depletion of glycogen in the slow twitch fibers of the muscle. As specific fiber depletion patterns could not be determined by the muscle glycogen assay used for this study, the nature of the pattern of depletion and reaccumulation occurring here remains a moot point. In light of the work cited above, however, selective slow twitch fiber depletion could explain the remaining muscle glycogen observed after endurance exercise testing. Furthermore, it must be emphasized that the results of this study, both in terms of exercise capability and rate of muscle glycogen utilization, are valid only for the type and intensity of exercise performed. Whether vastus lateralis glycogen would be equally well protected from oxidation at higher relative workloads or in exercise (such as cycling), which put greater demands on the specific muscle biopsied, remains to be tested.

Nonetheless, a very important finding of this study is the preservation of physical capacity for moderate exercise in the context of severe caloric restriction.
Although some marathon runners prefer to fast for 1 or more $\mathrm{d}$ in preparation of their event, total starvation is generally associated with poor physical performance. This has recently been confirmed by Drenick et al. (26), who found decreased exercise tolerance at $30 \%$ of $\mathrm{V}_{\mathrm{O}_{2} \max }$ in obese men fasted for $40 \mathrm{~d}$, although the subjects in the study were not pushed to maximal performance. The metabolic state achieved in the PSF is similar to that of fasting, but differs in that there is less elevation of circulating ketone levels, and the daily intake of protein both conserves lean body mass (27-29) and provides $\sim 50 \mathrm{~g}$ of gluconeogenic substrate. Regardless of the mechanism, however, these untrained subjects exhibited a sustained, or possibly improved, capability for moderate endurance exercise, while experiencing rapid weight loss.

The composition of the weight lost by the subjects was estimated by underwater weighing and 24 -h urine creatinine determinations. Whereas the former method indicated that $67 \%$ of the loss was fat, the latter method suggested a preservation of skeletal muscle during the 6 wk of supplemented fast, with the $2 \%$ decrease in 24 -h urine creatinine ( 1.73 to 1.69 , change not significant) from base line to the lst wk of the PSF being concurrent with the expected period of negative nitrogen balance early in such a diet $(27,28)$. Because the serum albumin remained stable throughout the study, it is unlikely that the remaining $33 \%$ of the weight loss was at the expense of the visceral protein pool. Rather, it is probable that a major portion of the nonfat weight loss represents intracellular and extracellular water lost secondary to the natriuresis associated with ketosis (30-32), as well as water lost in association with the approximately one-third depletion in muscle glycogen stores (normal stores, $500 \mathrm{~g}, 3 \mathrm{ml}$ of water stored with each $\mathrm{g}$ of glycogen, hence $670 \mathrm{~g}$ of intracellular contents lost).

There was a decrease in the mean oxygen uptake during the treadmill walking (from 76 to $60 \% \mathrm{~V}_{\mathrm{O}_{2} \max }$ ) after 6 wk of adaptation, despite constant treadmill speed and angle, as well as maintenance of constant weight for each subject through the use of a backpack. Multiple factors may have contributed to this observation, but were not measured in this experiment. These included decreased basal metabolic rate, decreased hobbling secondary to reduced lower extremity adipose tissue, and improved walking technique of the subjects on the treadmill (although subjects had three practice periods before the first PSF endurance test).

It is interesting in view of the reduced energy use during exercise following the ketogenic diet in these studies that not only were the resting concentrations of $T_{3}$ decreased, but the exercise itself induced a further shift in the same direction. The response to exercise was similar to that observed in normal sub- 
jects during 3-5 $\mathrm{h}$ of moderate exercise (12). Whether, as in starvation, these changes in concentration of $T_{3}$ reflect changes in the peripheral metabolism of $T_{4}$ and $T_{3}$, or might be partially responsible for the reduced energy utilization during exercise is not known. The small increase in concentrations of $\mathrm{T}_{4}$ with exercise (despite correction for hemoconcentration) is unlikely to be secondary to increased thyroidal secretion inasmuch as $\mathrm{T}_{3}$ concentrations fell.

One may conclude from this study that prolonged moderate endurance exercise can be performed by subjects on a protein-supplemented fast (in the context of appropriate fluid, mineral, and vitamin therapy). Optimum function of this regimen requires an adaptation period $>1 \mathrm{wk}$, and possibly $6 \mathrm{wk}$ or more. Adaptation occurs in conjunction with a marked reduction in the utilization of blood glucose and muscle glycogen as metabolic substrates for exercise. It is not clear that the circulating ketone bodies play a primary role in the observed maintenance or improvement in endurance exercise function. The observed effect could be due to the sustained elevation of the FFA level, including improved transport across the mitochondrial membrane, or increased capability for fatty acid oxidation within the mitochondrian. Further studies are in progress to delineate better the metabolic adaptation that occurs with prolonged ketosis, and to study the relationships among endurance performance, exercise type, and exercise intensity.

\section{ACKNOWLEDGMENTS}

We wish to thank the staff of the Clinical Research Center for nursing support; Vivien Ho for assistance with the dietary planning and calculations; Takamaru Ashikaga and Michael Willcutts for help with statistical evaluation; Catherine Armstrong, Maureen O'Connell, and Stephanie Feloney for technical assistance; and Nancy Perrine and Paula Zaborski for typing the manuscript.

Data organization and statistical analysis were performed (in part) on the PROPHET system, sponsored by the Chemical/ Biological Information Handling Program, National Institutes of Health, Bethesda, Md.

This work was supported in part by U. S. Public Health Service grants AM 10254 (Dr. Sims), AM 18535 (Dr. Danforth), and RR-109 (General Clinical Research Center).

\section{REFERENCES}

1. Christensen, E. H., and O. Hansen. 1939. Zur Methodik der respiratorischen Quotient-Bestimmungen in Ruhe and bei Arbeit. II. Untersuchungen ueber die Verbrennungsvorgaenge bei langdaurnder, schwerer Muskelarbeit: Arbeits Faehigkeit und Ernahrung. Skand. Arch. Physiol. 81: 137-171.

2. Bergstrom, J., and E. Hultman. 1967. A study of the glycogen metabolism in man. J. Clin. Lab. Invest. 19: 218-229.

3. Hultman, E. 1967. Studies on muscle metabolism of glycogen and active phosphate in man with special reference to exercise and diet. Scand. J. Clin. Lab. Invest. 19(Suppl. 94): 1-63.

4. Saltin, B., and J. Karlsson. 1971. Muscle glycogen utilization during work of different intensities. In Muscle Metabolism During Exercise. B. Pernow and B. Saltin, editors. Plenum Publishing Corp., New York. 2: 289-299.

5. Kark, R., R. Johnson, and J. Lewis. 1946. Defects of pemmican as an emergency ration for infantry troops. War Med. 8: 345-352.

6. Stefansson, V. 1956. The Fat of the Land. Macmillan, Inc., New York. 40-59.

7. McClellan, W. A., and E. F. DuBois. 1930. Clinical calorimetry XLV. Prolonged meat diets with a study of kidney function and ketosis. J. Biol. Chem. 87: 651-668.

8. McClellan, W. S., V. R. Rupp, and V. Toscani. 1930. Clinical calorimetry. XLVI. Prolonged meat diets with a study of the metabolism of nitrogen, calcium, and phosphorus. J. Biol. Chem. 87: 669-680.

9. Goldman, R. F., and E. R. Buskirk. 1961. A method for underwater weighing and the determination of body density. In Techniques for Measuring Body Composition. J. Brozek and A. Heuschel, editors. National Academy of Science-National Research Council. 78.

10. Scholander, P. F. 1947. Analyzer for accurate estimation of respiratory gases in one-half cubic centimeter samples. J. Biol. Chem. 167: 235-250.

11. Horton, E. S., C. Johnson, and H. E. Lebovitz. 1968. Carbohydrate metabolism in uremia. Ann. Intern. Med. 68: 63-74.

12. O'Connell, M., D. C. Robbins, E. S. Horton, E. A. H. Sims, and E. Danforth, Jr. 1979. Changes in serum concentrations of $3,3^{\prime}, 5^{\prime}$-triiodothyronine (reverse $T_{3}$ ) and 3,5,3'-triiodothyronine $\left(\mathrm{T}_{3}\right)$ during prolonged moderate exercise. J. Clin. Endocrinol. Metab. 49 (2): 242-246.

13. Cornwal, A. G.,C. J. Baebawill, and M. M. David. 1949. Determination of serum proteins by means of the biuret reaction. J. Biol. Chem. 177: 751-766.

14. Bergmeyer, H. V. 1974. Methods of Enzymatic Analysis. Academic Press, New York. 1212-1220.

15. Novak, M. 1965. Colorimetric ultra micro method for the determination of free fatty acids. J. Lipid Res. 6: 431-433.

16. Snedecor, G. W., and W. G. Cochran. 1967. Statistical Methods. The Iowa State University Press, Ames, Iowa. 6th edition. 258-275.

17. Astrand, P., and K. Rodahl. 1977. Textbook of Work Physiology. McGraw-Hill, Inc., New York. 408-409.

18. Krogh, A., and J. Lindhard. 1920. Relative value of fat and carbohydrates as sources of muscle energy. Biochem. J. 14: 290.

19. Marsh, M. E., and J. R. Murlin. 1928. Muscular efficiency on high carbohydrate and high fat diets. J. Nutr. 2: 105-137.

20. Apfelbaum, M., A. Reinberg, and F. Duret. 1978. Effect of voluntary restricted diets on physical fitness in sedentary work conditions. In Nutrition, Physical Fitness, and Health. International Series on Sport Sciences. J. Parizkova and V. A. Rogozkin, editors. University Park Press, Baltimore, Md. 7: 248-256.

21. Randle, P. J., P. B. Garland, C. N. Hales, E. A. Newsholme, R. M. Denton, and C. I. Pogson. Interactions of metabolism and the physiologic role of insulin. Recent Prog. Horm. Res. 22: 1-48.

22. Owen, O. E., and G. A. Reichard, Jr. 1971. Human forearm metabolism during progressive starvation.J. Clin. Invest. 50: 1536-1545.

23. Hagenfeldt, L., and T. Wahren. 1971. Human forearm muscle metabolism during exercise. VI. Substrate utiliza- 
tion in prolonged fasting. Scand. J. Clin. Lab. Invest. 27: 299-306.

24. Costill, D. L., K. Sparks, R. Gregor, and C. Turner. 1971. Muscle glycogen utilization during exhaustive running. J. Appl. Physiol. 31: 353-356.

25. Costill, D. L., E. Jansson, P. D. Golnick, and B. Saltin. 1974. Glycogen utilization in leg muscles of men during level and uphill running. Acta Physiol. Scand. 91: 475-481.

26. Drenick, E. J., J. S. Fisler, D. G. Johnson, and G. McGhee. 1977. The effect of exercise on substrates and hormones during prolonged fasting. Int. J. Obesity. 1: 49-61.

27. Blackburn, G. L., J. P. Flatt, and G. H. A. Clowes. 1973. Protein sparing therapy during periods of starvation with sepsis and trauma. Ann Surg. 177: 588-594.
28. Apfelbaum, M. 1976. The effects of very restrictive high protein diets. Clin. Endocrinol. Metab. 5: 417-430.

29. Genuth, S. M., J. H. Castro, and V. Vertes. 1974. Weight reduction in obesity by outpatient semistarvation. JAMA (J. Am. Med. Assoc.) 230: 987-991.

30. Sigler, M. H. 1975. The mechanism of the natriuresis of fasting. J. Clin. Invest. 55: 377-387.

31. Sparks, R. F., R. A. Arky, P. R. Boulter, C. D. Saudek, and J. T. O'Brian. 1975. Renin, aldosterone, and glucagon in the natriuresis of fasting. N. Engl. J. Med. 292: 13351340.

32. Kolanowski, J., G. Salvador, P. Desmecht, J. C. Henquin, and J. Crabbe. 1977. Influence of glucagon on natriuresis and glucose-induced sodium retention in the fasting obese subject. Eur. J. Clin. Invest. 7: 167-175. 